\title{
The Impact of Foreign Direct Investment from Major Source Countries on Turkish Trade with the European Union
}

Rahmi Cetin, Sami Taban*

Abstract:

The available literature on the relationship between foreign direct investment (FDI) and trade has so far shown mixed results. Although traditional trade theory showed that factor movements and trade are a perfect substitute, new trade and FDI theories argue that factor movements and trade can be either a substitute or complementary to each other, depending on the types of investment made by multinational enterprises (MNEs) and macroeconomic policies used by the host countries. This paper attempts to test empirically the existence of $a$ long-run relationship between inward FDI and the trade performance of Turkey over the period 1976-2006 by applying the multivariate cointegration technique of Johansen and Juselius (1990). In particular, the effects of FDI from major source countries (i.e., the US, Japan, and the EU) are examined to see whether they have different impacts on Turkish trade with the EU. The results of the long-run export supply model indicate that both Japanese and EU FDI play a significant role in the level of Turkish exports to the EU market, while US FDI causes a reduction in the level of Turkish exports to the EU. Similarly, the results of the long-run import demand model show that EU FDI contributes the level of Turkish imports from the EU by raising demands for intermediate and capital goods from the home market, while Japanese FDI led to a decrease in the level of Turkish imports from the EU market.

Keywords: foreign direct investment, trade, Turkey.

JEL: C22, F21, F19.

DOI: $10.2478 / \mathrm{v} 10033-009-0013-4$

\section{Introduction}

The extent of multinational activity in the world economy and the share of world trade accounted for by multinational enterprises have risen steadily over time with the removal of national barriers to capital movements and integration of regional markets. For instance, the gross product associated with international production accounted for $10 \%$ of world GDP and onethird of world exports in 2006 (UNCTAD, 2007). Voluminous theoretical literature has been written on the relationship between FDI and trade flows (see for example, Mundell, 1957; Purvis, 1972; Kojima, 1973 and 1982, Helpman, 1984, Markusen, 1984 and 1995). Kojima's hypothesis is of particular interest to this study, as his theory points out the different trade impacts of FDI inflows from different source countries.
Parallel to these developments, Turkey adopted liberal economic policies in 1980 and created a favourable environment for foreign investors to increase Turkey's international competitiveness and allow Turkey to achieve high levels of economic growth. Since the

*Rahmi Cetin

Faculty of Economics and Administrative Sciences,

Department of Economics

e-mail:crahmi@hotmail.com

\section{Sami Taban}

Faculty of Economics and Administrative Sciences, Department of Economics, Eskişehir Osmangazi University

e-mail: staban1@hotmail.com 
beginning of the 1980 program, actual FDI flows to the country increased steadily from $\$ 823$ million in 1999 to \$4.2 billion in 2004 and then to \$19.1 billion in 2006 . Turkey attracted 82\% of its total FDI from the EU in 2006. As a result, the importance of FDI in Turkey's total investment increased rapidly from 5\% in 2004 to $20 \%$ in 2006 (IMF, 2007). Similarly, Turkey also achieved a tremendous level of growth in its exports and imports during the last three decades. The volume of bilateral trade with the EU has considerably increased over the last decade, especially after the completion of the customs union (Ulgen and Zahariadis, 2004). Turkey became the seventh largest trade partner of the EU, following the USA, China, Russia, Switzerland, Japan and Norway (Trade-EC-Europa, 2007:3). Is this a coincidence, or is there a special relationship between FDI and trade level? In light of these developments in the Turkish economy, this paper is designed to investigate the impact of FDI on the trade performance of Turkey.

The rest of the paper is organized as follows. Section 2 consists of a brief review of the theories explaining the relationship between FDI and trade. Section 3 sets out export and import models. Section 4 contains the methodology and the interpretations of the estimation results from econometric models. Section 5 summarizes the main conclusions.

\section{Theoretical Background}

The earliest theoretical explanation of the relationship between trade and FDI was given by Mundell (1957), who argued that commodity trade is at least to some extent a substitute for factor movements or vice versa, since trade is assumed to be explained by differences in factor endowments. This implies that an increase in trade impediments stimulates factor movements, while an increase in restrictions to factor movements stimulates trade. Mundell also explored the special case where trade and factor movements are perfect substitutes. Under restrictive assumptions of zero transport costs, no market distortions, no economies of scale, and identical production technology, Mundell argued that free trade tends to equalise factor prices through the equalisation of commodity prices, even when factors are immobile between the two countries. It is equally true that perfect capital mobility tends to equalise commodity prices through the equalisation of factor prices, even when commodity movements are not allowed. However, the substitution model of Mundell was challenged by Purvis
(1972), Kojima (1973), Markusen (1984), and Markusen and Venables (1998) on the basis of imperfect competition. The real world is characterised by market distortions, such as trade barriers, transport costs, differences in production technologies and factor endowments, etc.

In contrast to Mundell's substitution model, Purvis (1972) proposed a model where capital movements and trade complement each other. He argued that foreign investment is complementary to commodity trade, if it creates and/or expands the opportunity to import one product and to export the other. Purvis obtains such complementarity by relaxing the assumption of identical production technology between two countries. Consider a model of two countries, $A$ and $B$, which produce two goods, $X$ and $Y$, respectively, with two factors of production, capital and labour. Assume that country $A$ is capital-abundant relative to country $B$ and good $Y$ is capital-intensive relative to good $X$. Also assume that country $B$ has comparatively higher capital productivity in good $Y$ than country $A$. If there are no barriers to capital movements, capital flows from country A to country B until the marginal productivity of capital is equalised between the two countries. After capital movements, the increased output of good $Y$ in country $B$ is expected to be more than the decreased output of good $Y$ in country $A$.

Kojima (1973, 1975, 1982, and 1995) further developed the Mundell and Purvis models and specified the conditions for FDI to be a substitute or complementary to commodity trade. He played a pioneering role in developing a systematic macroeconomic approach to FDI and in integrating FDI with conventional trade theory. In order to explain the link between FDI and trade, Kojima (1975) distinguished FDI from international money transfer and argued that FDI involves not only the transfer of money, but also the transplantation of production technology through training labour, engineers, and managers. Kojima argued that if FDI takes place in labour-intensive industries where the host country (developing) has comparative advantages, it improves the productivity of the host country and therefore creates more trade with the investing country. This is because the smaller the technological gap between the investing and host countries, the easier it is to transplant production technology and improve the productivity of the host country. However, FDI which takes place in the capitalintensive sectors are trade-substitute or importsubstituting. Although the theory can be applied to FDI 
flows between industrialised countries and developing countries, it does not explain "two-way" investments between industrialised countries. This gap in the trade literature was noticed by Arndt (1974), Geroski (1979), Mason (1980), Buckley (1983), and Lee (1984) and filled by the "new" trade theory.

In light of this hypothesis, Kojima made a distinction between Japanese and US FDI. The former was originated in labour-intensive and resource-based industries in which Japan was losing comparative advantage, while the latter was originated in $R \& D$ intensive industries in which the US was gaining comparative advantage. As a result, Japanese FDI was trade-oriented, since such investment fits the host country's comparative advantage. On the other hand, US FDI was anti-trade-oriented, since such investment does not fit the host country's comparative advantage, and eventually reduces the total output of the two countries and their trade volume. In other words, Japanese-type FDI expands exports from the host developing countries, while the US-type FDI results in import-substitution for the host developing countries. The hypothesis that Japanese FDI is more trade-oriented than US FDI was tested empirically for a group of Asian and Latin American countries. This paper will conduct such a test for the Turkish economy by incorporating EU FDI into the system.

Since the early 1980 s, a small number of international economists have constructed new models to integrate FDI into trade theories. Markusen (1984), Brainard (1993), Horstmann and Markusen (1992), Markusen (1995), and Markusen and Venables (1998) produced models to integrate horizontal FDI into trade theory. Horizontal FDI consists of the duplication of the entire production process in several countries. The three key elements of these models are firm-level activities, such as research and development, which are joint inputs across plants, plant-level scale economies, and tariffs or transport costs between countries. According to Brainard (1993) and Horstmann and Markusen (1992), when countries are identical in technologies, preferences, and factor endowments, the higher the value of firm-level fixed costs and tariffs and transport costs relative to plant-level fixed costs, the more likely the presence of horizontal FDI. Contrary to conventional trade theory, trade cannot be explained by comparative advantages, since the countries have similar market size, technologies, and factor endowments. Here, horizontal FDI is likely to replace trade, since the countries invest in each other to produce same products with little variation.

Markusen and Venables (1998) further elaborated the theory to introduce asymmetries between countries in terms of market size, technologies, and factor endowments. According to this model, horizontal direct investments will dominate international economic activities when countries become more similar in market size, technology, and relative factor endowments, provided that transport costs are not too small. Here horizontal FDI is a substitute for international trade. However, when the countries are moderately different in any of these characteristics, demands from the disadvantaged country will be met through both direct investments of MNEs and exports of national firms in the advantaged country. When the degree of difference is very large, MNEs will leave the disadvantaged country completely and exports will dominate international trade between the countries.

The literature on foreign direct investment also fails to give a clear-cut relationship between FDI and trade. There are two well-known perspectives in this field: the product cycle theory of Vernon (1966) and the eclectic paradigm of Dunning (1993). According to the product cycle theory, the relationship between FDI and trade is dynamic and changes depending on the stage of the life cycle of a new product. In the first stage of the product cycle, demand from another developed country is satisfied through the exports of an innovating firm. In the second stage, competitors in another developed country acquire firm-specific knowledge of the innovating firm and cost considerations become important. In order to remain competitive and keep its market share, the innovating firm moves its production unit to that country. Therefore, for a single product firm, FDI is viewed as a substitute for the exports of this good from the investing country. In the final stage, production costs become very important for both the innovating firm and its competitors. Therefore, they shift their production units to low-cost locations (i.e., developing countries) and export goods from these countries back to their home countries. Here FDI is viewed as a complement to trade when both countries have different factor endowments.

On the other hand, the eclectic paradigm classifies four types of FDI to explain the relationship between FDI and trade flows. First, resource-seeking FDI relates to the exploitation of natural resources in the host countries. This type of FDI takes place between a resource-rich country and a developed country and therefore is trade- 
oriented; the former exports resource-intensive products, while the latter may export agricultural and mining equipments. Second, market-seeking FDI aims to supply final goods to a host country. Market-seeking FDI is often called "import-substituting FDI" since it replaces the exports of final products from the home country. Third, efficiency-seeking FDI occurs when MNEs shift part of their value-added chain to lower cost locations to increase the profitability of their overall operations. For instance, to improve their efficiencies, MNEs move labourintensive segments of their production process to developing countries. This type of FDI generally creates trade, since it gives rise to the exports of labour-intensive products and promotes the exports of raw materials and intermediate goods from the home countries. Finally, strategic asset-seeking FDI usually arises at an advanced stage of the globalisation of a firm when the firm invests in a developed country in order to acquire $R \& D$ capabilities. This type of FDI is also predominantly export-oriented and usually promotes the exports of high-skilled labour services from developing countries and gives rise to the export of services and equipments from the home countries.

\section{The Model}

To analyse the relationship between FDI from three source countries and Turkish trade with the EU, two types of models were constructed: export supply and import demand. Following the models of Ramstetter (1986), Naya and Ramstetter (1992), Goldberg and Klein (1997) and Mankovska (2001) and given foreign and national income levels, export supply and import demand were estimated as the functions of domestic investment (DI), FDI from the US(Al), Japan (JI), and the EU (El), and the real exchange rates (ER). Annual domestic investment data was obtained by subtracting FDI data from gross fixed capital formation (GCF). Real exchange rate was used as a proxy for the export and import price indices.

FDI inflows from the US, Japan, and the EU to host countries show different characteristics because of differences in the industrial development of these source countries and differences in the economic structure of recipient countries (Kojima, 1973 and 1982). Kojima argued that Japanese FDI is more trade-oriented than the US FDI, since most Japanese FDI takes place in the labourintensive and/or resource-oriented industries, where the host developing countries have comparative advantages. This theory has been tested by a number of empirical works. The main contribution of this paper to the empirical literature is to add the EU FDI into the trade models. Following the above empirical studies and assuming "infinite" export demand and import supply elasticities, the export supply and import demand equations for Turkey can be written as follows:

$X E_{t}=a_{0}+a_{1} D I_{t}+a_{2} A I_{t}+a_{3} J_{t}+a_{4} E I_{t}+a_{5} E R_{t}+u_{t}$
$M E_{t}=\beta_{0}+\beta_{1} D I_{t}+\beta_{2} A I_{t}+\beta_{3} J_{t}+\beta_{4} E I_{t}+\beta_{5} E R_{t}+v_{t}$

where $u$ and $v$ denote serially uncorrelated error terms with zero mean and constant variances and $t$ is time period.

The reasons why these variables were selected and their likely impacts on trade are several. The relationship between inward FDI and exports for developing countries has been investigated in a number of empirical studies (e.g., Abe, 1983; Kojima, 1985; Ramstetter, 1986; Gullett, 1990; Naya and Ramstetter, 1992; Goldberg and Klein, 1997). According to the existing theories, the overall impact of inward FDI on the exports of host developing countries are not predictable. For instance, if the host country has a large and protected domestic market, FDI is more likely to produce for the domestic market. Alternatively, if FDI takes place in a host country because of cheap labour and natural resources, then FDI is more likely to improve the export competitiveness of the host country through exploiting the abundant factors of production. Therefore, either a positive or negative relationship is expected between inward FDI and exports.

As for the relationship between inward FDI and imports from the host developing countries, again either a positive or negative relationship can arise. It is argued in the literature that while the essence of FDI leads to an increase in the level of imports of intermediate and capital goods, there is also substitution of imports with the local production of consumer goods in the host countries. For instance, if multinational firms start producing goods in the host country as a reaction to high tariffs or any other reason, then imports of those goods would decrease or stop completely.

Domestic investment has been included as another explanatory variable and was found to have a positive and significant impact on the country's export performance. Examples of these empirical studies include Ramstetter, 1986; Gullett, 1990; Orr, 1991; Naya and Ramstetter, 1992; Leichenko and Erickson, 1997; and Sun, 2001. Therefore, a positive sign on the coefficient of domestic investment is expected in our export models. 
However, the relationship between domestic investment and import level is not predictable. They can be either positively or negatively related to each other, depending on the type of economic policies adopted by the country concerned. If the country follows import substitution policies, domestic investment is likely to reduce the level of imports. On balance, the value of import creation (the need for foreign intermediate and capital goods) is outweighed by the value of import substitution. On the other hand, if the country adopts export promotion policies, then domestic investment is more likely to increase the level of imports. In this case, the value of import substitution is outweighed by the value of import creation.

Finally, the real exchange rate variable, which was included in the trade models, has also been studied by a number of empirical works, and these works have established significant relationships between the real exchange rates and trade (e.g., Frankel and Wei, 1993; Gagnon, 1993; Bayoumi et al., 1996; and Goldberg and Klein, 1997). An appreciation of the exchange rate (a decrease in the mean level of the exchange rate) increases (decreases) the expected profits of importers (exporters), thus resulting in an increase (decrease) in import (export) volume. The opposite effect occurs in the case of an increase in the mean level of the exchange rate (currency depreciation). Therefore, based on the Turkish currency value of a foreign currency, imports are expected to be negatively associated with changes in real exchange rates, while exports are expected to be positively associated with changes in real exchange rates.

\section{Methodology and Test Results}

Before testing for cointegration, the order of integration of the individual time series must be determined. This study performed both Augmented Dickey-Fuller (ADF) (1979) and Phillips-Perron (PP) (1988) tests to examine the order of integration of the series included in the analysis by the following equations:

$$
\begin{aligned}
& \Delta y_{t}=a+\delta y_{t-1}+\varepsilon_{t} \\
& \Delta y_{t}=a+\delta y_{t-1}+\sum_{i=1}^{k} \gamma_{i} \Delta y_{t-i}+\varepsilon_{t}
\end{aligned}
$$

where $\Delta y$ is the first difference of $y$ series, $\alpha$ is a constant term, $\varepsilon_{\mathrm{t}}$ is the residual term and $\mathrm{k}$ is the lagged values of $\Delta y_{t}$, which is included to avoid serial correlation in the residuals. In the context of the ADF test, a test for non-stationary of the series, $y$, amounts to a ttest of $\delta=0$. The alternative hypothesis of stationary test requires that $\delta$ be significantly negative. If the absolute value of the computed t-statistics for $\delta$ exceeds the absolute critical value, then the null hypothesis that the log level of $y$ series is not stationary must be rejected. If, on the other hand, it is less than the critical value, it can be concluded that the log level of $y$ is non-stationary. In this case, the same regression must be repeated for the first difference of the logarithmic value of the series. The appropriate lag order of $k$ in equation (3) was chosen on the basis of the Akaika Information Criteria (AIC).

Variables used in the trade models include real exports to the EU (XE); real imports from the EU (ME); FDI from the USA (AI), the EU (EI), and Japan (JI); real domestic investment (DI); and real effective exchange rate (ER).

The results of the ADF and PP unit root tests of the seven variables applied to both levels and the first differences of the variables are reported in Table 1.

\begin{tabular}{|c|c|c|c|c|}
\hline \multirow{2}{*}{ Variable } & \multicolumn{2}{|c|}{ Level } & \multicolumn{2}{c|}{ First Difference } \\
\cline { 2 - 5 } & ADF & PP & ADF & PP \\
\hline XE & $-0.92(7)$ & 0.29 & $-3.35^{*}(7)$ & $-7.52^{* *}$ \\
\hline $\mathrm{ME}$ & $-0.32(2)$ & 0.12 & $-5.45^{* *}(1)$ & $-6.70^{* *}$ \\
\hline $\mathrm{DI}$ & $-0.92(0)$ & -0.92 & $-3.33^{*}(7)$ & $-6.55^{* *}$ \\
\hline $\mathrm{Al}$ & $-1.93(0)$ & -1.68 & $-6.37^{* *}(0)$ & $-8.31^{* *}$ \\
\hline $\mathrm{JI}$ & $-1.62(0)$ & -1.61 & $-5.45^{* *}(0)$ & $-5.45^{* *}$ \\
\hline $\mathrm{EI}$ & $-0.76(0)$ & -0.29 & $-6.58^{* *}(0)$ & $-7.40^{* *}$ \\
\hline $\mathrm{ER}$ & $-1.63(0)$ & -1.60 & $-6.00^{* *}(0)$ & $-6.00^{* *}$ \\
\hline
\end{tabular}

Note: For the ADF test, numbers inside brackets are the numbers of lags selected by the AIC method. Superscripts ** and * denote rejection of the null hypothesis at the $1 \%$ and $5 \%$ significance levels. The critical values for ADF and PP are based on Mackinnon (1996).

Table 1: Unit Root Test Results

The results of unit root tests for the level of time series indicate that the null hypothesis that the time series has a unit root cannot be rejected for any variable. However, when the ADF and PP tests are applied to the first differences of each variable, all first differenced variables are seen as stationary. Based on these results, it is assumed that they are all integrated in the same order of one, that is I(1). The fourth column of Table 1 reports the ADF test results on the first differences of the variables.

Since Turkey signed a customs union with the EU at the end of 1995, a structural break on XEU data is 
expected. In order to examine whether any structural break occurred in the series due to this agreement we utilised Perron's (1989) structural break test. The author proposed three alternative models to test unit root with structural break; crash model (i.e., a shift in the intercept), changing growth model (i.e., a change in the slope) and change both in the intercept and in the slope. Because of the nature of this event this study preferred the second model (Model 2). To check whether a structural break happened in the relevant series the following equation was estimated by OLS and tested the negativity of $\eta$.

$$
\begin{aligned}
\Delta y_{t}=\alpha+\beta t+ & \delta D L+\gamma D T+\eta y_{t-1}+ \\
& +\sum_{i=1}^{k} \beta_{i} \Delta y_{t-i}+\varepsilon_{t}
\end{aligned}
$$

where $\mathrm{t}$ is time trend; $D L=1$ for $\mathrm{t}=\mathrm{Tb}+1$ and 0 otherwise, where $\mathrm{Tb}$ is the break year; DT $=\mathrm{t}-\mathrm{Tb}$ if $\mathrm{t}>\mathrm{Tb}$ and 0 otherwise; and $\Delta$ is the first difference operator.

Structural break test results for XEU data are presented in Table 2. Since the computed values of $\mathrm{t}$ statistics for $y_{t-1}$ is smaller than the critical values there is no spurious root generated by the customs union on the XEU data. Therefore, we do not need to incorporate a slope dummy variable in the export function, which will be estimated in the following section.

\begin{tabular}{|c|c|c|c|c|c|}
\hline$T b$ & $k$ & $\beta$ & $\delta$ & $\gamma$ & $\eta$ \\
\hline 1995 & 3 & 3.42 & -1.29 & -0.45 & -3.71 \\
\hline
\end{tabular}

Note: The critical values for 70 observation were reported by Perron $(1997 ; 362)$ in Table 1. The critical values of t-statistics for Model 2 is $5.29,-5.59$, and -6.32 at the $10 \%, 5 \%$, and $1 \%$ levels. The optimum lag structure $(k)$ is determined by the AIC.

Table 2: Structural Break Test Results for XEU using data from 19762006

All time series data required by the given trade models are found to be stationary in first differences. Therefore, the next step is to test whether there is a cointegration (a long-run relationship) among the set of variables or not. Since Engle-Granger's (1987) two-step methodology is criticized for several shortcomings ${ }^{1}$, this

\footnotetext{
1 These shortcomings include (a) the arbitrary normalization of the cointegration vector, (b) the assumption of one cointegrating vector in systems with more than two variables and (c) biased OLS estimators (biased OLS estimators may be due to the exclusion of short-run dynamics and the presence of endogenous explanatory variables). Furthermore, due to the non-normality of the distribution of the
}

study employed the Johansen and Juselius (1990) multivarite cointegration approach.

To carry out the Johansen and Juselius test, vector autoregression model (VAR) can be formulated as follows:

$$
\mathrm{y}_{\mathrm{t}}=\Gamma_{1}(\mathrm{~L}) \mathrm{y}_{\mathrm{t}-1}+\Gamma_{2}(\mathrm{~L}) \mathrm{y}_{\mathrm{t}-1}+\ldots+\Gamma_{\mathrm{p}}(\mathrm{L}) \mathrm{y}_{\mathrm{t}-1}+\varepsilon_{\mathrm{t}-\mathrm{p}}
$$

where $\mathrm{y}_{\mathrm{t}}=(\mathrm{XE}$ or $\mathrm{ME}, \mathrm{DI}, \mathrm{Al}, \mathrm{Jl}, \mathrm{El}, \mathrm{ER})$ is a column vector and $\Gamma_{1}(\mathrm{~L})$ with $\mathrm{i}=1, \ldots, \mathrm{p}$ is a lag operator. $\varepsilon$ is the white noise residual of zero mean and constant variance.

The number of cointegration vectors [the cointegration rank], $r$, can be formally tested with the trace and maximum-eigenvalue statistics. The trace statistic tests the null hypothesis that the number of distinct cointegration vectors is less than or equal to $r$ against the general alternative of $n$ cointegrating vectors. The maximum-eigenvalue test evaluates the null

\begin{tabular}{|c|c|c|c|c|}
\hline \multicolumn{5}{|c|}{$\begin{array}{l}\text { Series: XE, DI, Al, Jl, El, ER } \\
\text { Lag-length: } 1\end{array}$} \\
\hline \multicolumn{2}{|c|}{ Trace statistics } & \multicolumn{2}{|c|}{ Max-Eigen statistics } & \multirow{2}{*}{$\begin{array}{c}\text { Hypothesized } \\
\text { No. of } \\
\text { Cointegrating } \\
\text { vectors }\end{array}$} \\
\hline Statistics & $\begin{array}{l}\text { Critical } \\
\text { Value } \\
0.05 \%\end{array}$ & Statistics & $\begin{array}{l}\text { Critical } \\
\text { Value } \\
0.05 \%\end{array}$ & \\
\hline 117.66 & 103.84 & 35.19 & 40.95 & None* \\
\hline 82.47 & 76.97 & 30.39 & 34.80 & At most $1^{*}$ \\
\hline 52.07 & 54.07 & 27.59 & 28.58 & At most 2 \\
\hline 24.48 & 35.19 & 12.23 & 22.29 & At most 3 \\
\hline 12.24 & 20.26 & 8.57 & 15.89 & At most 4 \\
\hline 3.66 & 9.16 & 3.66 & 9.16 & At most 5 \\
\hline \multicolumn{5}{|c|}{$\begin{array}{l}\text { Series: ME, DI, Al, Jl, El, ER } \\
\text { Lag-length: } 1\end{array}$} \\
\hline 123.86 & 103.84 & 48.84 & 40.95 & None* \\
\hline 75.01 & 76.97 & 31.78 & 34.80 & At most 1 \\
\hline 43.22 & 54.07 & 19.69 & 28.58 & At most 2 \\
\hline 23.53 & 35.19 & 11.35 & 22.29 & At most 3 \\
\hline 12.17 & 20.26 & 6.74 & 15.89 & At most 4 \\
\hline 5.43 & 9.16 & 5.43 & 9.16 & At most 5 \\
\hline
\end{tabular}
hypothesis of $r$ cointegration vectors against the alternative of $r+1$ cointegration vectors.

* Denotes rejection of the hypothesis at the $5 \%$ level. The optimum laglengths are determined by the AIC.

Table 3: Johansen's Cointegration Test Results

Table 3 reports the trace and the maximumeigenvalue statistics from the cointegration tests based

estimators, no final judgment can be passed on the significance of the estimated coefficient (Herzer, Lehmann and Siliverstovs, 2004). 
on the VAR. In these tests, we examine the null hypotheses stating that the variables under consideration are not cointegrated against the alternatives and that there are at most 1 to 5 cointegrating equations.

While the trace test indicates two cointegrating vectors among the variables in equation (1), the maxeigen value test indicates no cointegration at the $5 \%$ level. On the other hand, both the trace and max-eigen test statistics indicate that there exists a unique cointegrating vector among the variables in equation (2).

The normalized cointegrating coefficients for equations ( 1 ) and (2) respectively are as follows:

$$
\begin{aligned}
& X E=5.682+0.117 D I-1.960 A I+0.403 J I+ \\
& \text { (0.434) (0.103) }(-4.933)^{* * *} \quad(2.766)^{* * *} \\
& + \text { 1.460EI + 0.372ER } \\
& (3.567)^{* * *} \quad(0.262)
\end{aligned}
$$

$$
\begin{aligned}
& \text { ME = -3.754 + 1.198DI + 0.126AI - 0.358J + } \\
& (-0.946) \quad(3.550)^{* * *} \quad(1.050) \quad(-8.379)^{* * *} \\
& \text { + 0.680EI - O.761ER } \\
& (5.193)^{* * *} \quad(-1.811)^{*}
\end{aligned}
$$

Notes: $\mathrm{t}$-values are given in brackets. $*^{*}, *$, and $* * *$ indicate significance at the $10 \%, 5 \%$, and $1 \%$ levels, respectively.

From equation (7), the following results are obtained. First, EU investment seems to have a positive and significant statistically impact on exports to the EU market. Turkish exports to the EU increase by 1.460 percent in response to a one percent rise in the level of EU FDI. The positive relationship between EU FDI and Turkish exports is well explained by the geographical proximity and cultural similarities between Turkey and Europe. Geographical and cultural distances prevent trade between countries, since extra costs have to be shared by the trading partners (Eaton and Tamura, 1994). A previous empirical study carried out by Cetin (2005) is also consistent with this finding. However, the size of the coefficient of EU FDI is quite large in the current work. This is understandable because of the time period studied and methodology used in both studies. Due to the time period selected in this study, the current study is more likely to capture the impact of the customs union agreement in 1995 on the export performance. Second, the estimated model provides strong evidence for the Kojima's theory since Japanese FDI is export-oriented, while the US FDI is ant-trade oriented. Finally, the coefficients of the real effective exchange rate and domestic investment, although they have expected signs, are not statistically significant.

The estimation of the import equation (8) provides the following results. First, domestic investment seems to have a positive and statistically significant impact on imports from the EU market. This result implies that domestic investors obtain most of the required capital and intermediate goods from the EU market. Second, FDI inflows from the EU and Japan impart significantly different effects on Turkish imports from the EU countries. EU FDI is shown to have a positive and statistically significant impact on imports from the EU market. The import creation effect of such FDI can be explained in two ways; a) one reason is that the subsidiaries of EU firms, which operate in Turkey, depend on foreign capital and intermediate goods in order to produce final goods for the export market; b) another reason is that the existence of EU subsidiaries, together with the geographical proximity to the EU market, creates additional demand for complementary products, which are produced by the same or competing EU firms. Third, Japanese FDI is shown to impart a negative and statistically significant effect on imports from the EU market. The import substitution effect of Japanese FDI can be related to the concentration of some Japanese firms in the production of capital-intensive goods previously imported from EU countries. Finally, there is a significant relationship between real effective exchange rates and imports from the EU at the 10 percent level. This means that demand for foreign inputs from the EU is price elastic in the longrun. Particularly, the depreciation of the Turkish lira against foreign currencies (an increase in the value of real effective exchange rates between 1988-1990, 1994-2000, and 2001-2005) leads to decreases in the level of Turkish imports from EU countries.

Since the set of variables in the estimated export and import models (equations 7 and 8) are said to be cointegrated, it is possible to construct dynamic short-run error correction models (ECMs). The short-run ECMs used in this paper are obtained from the cointegrating regressions (equations 7 and 8 ) as follows:

$$
\begin{aligned}
& \Delta X E_{t}=+\sum_{i=1}^{n} \alpha_{1 i} \Delta X E_{t-i}+\sum_{i=0}^{n} \alpha_{2 i} \Delta D I_{t-i}+\sum_{i=0}^{n} \alpha_{3 i} \Delta A I_{t-i}+ \\
& +\sum_{i=0}^{n} \alpha_{4 i} \Delta J I_{t-i}+\sum_{i=0}^{n} \alpha_{5 i} \Delta E I_{t-i}+\sum_{i=0}^{n} \alpha_{6 i} \Delta E R_{t-i}+\alpha_{7} E C_{t-1}+u_{t}
\end{aligned}
$$


$\Delta M E_{t}=+\sum_{i=1}^{n} \beta_{1 i} \Delta M E_{t-i}+\sum_{i=0}^{n} \beta_{2 i} \Delta D I_{t-i}+\sum_{i=0}^{n} \beta_{3 i} \Delta A I_{t-i}+$
$+\sum_{i=0}^{n} \beta_{4 i} \Delta J I_{t-i}+\sum_{i=0}^{n} \beta_{5 i} \Delta E I_{t-i}+\sum_{i=0}^{n} \beta_{6 i} \Delta E R_{t-i}+\beta_{7} E C_{t-1}+v_{t}$

where ECt-1, is the lagged error correction term these factors, it was also found that FDI plays a significant role in Turkish trade performance. In testing the validity of an extended version of the Kojima's theory, FDI inflows from the USA, Japan, and the EU were incorporated into the bilateral export and import functions. The following results were obtained from the estimations.

The estimation results of the long-run export model obtained from the cointegrating regressions; ut and vt are serially uncorrelated error terms; $a 7$ and $\beta 7$ depict the speeds of adjustment of the variables XE and ME to the long-run equilibrium respectively. The estimated coefficients of the short-run ECMs for the export supply function (XE) are obtained by the ordinary least squares (OLS) and the results are reported here with diagnostic tests in Table 4.

As Table 4 shows, the estimated shortrun export and import models pass through the various diagnostic tests. The residuals seem to have no serial correlation, no autoregressive conditional heteroscedasticity, and no non-normality and specification error.

The error correction terms, $\mathrm{EC}_{\mathrm{t}-1}$, are statistically significant and have the expected negative sign. The values of -3.94 and -1.46 imply that the adjustment of the actual values towards the long-run equilibrium takes place faster in the export model than in the import model. ${ }^{2}$ In addition, all the estimated short-run coefficients are consistent with the long-run coefficients except for American, Japanese, and the European FDI in the export function.

\section{Conclusion}

This paper investigated the relationship between inward FDI and Turkish trade with the EU over the period 1976-2006 by employing a multivariate cointegration approach. Previous empirical studies considered the flexible exchange rate regime, liberalisation of import policy, incentive schemes, and proximity to export markets as the main factors behind the success of Turkey's trade performance. In addition to

\footnotetext{
${ }^{2}$ The speed of adjustment to the long-run equilibrium level caused by each independent variable in the short-run is presented via the generalised impulse-response analysis results in Appendix II.
}

\begin{tabular}{|c|c|c|c|c|}
\hline & \multicolumn{2}{|c|}{ Dependent Variable: $\Delta \mathrm{XE}$} & \multicolumn{2}{|c|}{ Dependent Variable: $\Delta \mathrm{ME}$} \\
\hline Variable & Coefficient & t-Statistic & Coefficient & t-Statistic \\
\hline $\mathrm{EC}_{\mathrm{t}-1}$ & -3.943 & $-5.373^{* * *}$ & -1.467 & $-5.385^{* * *}$ \\
\hline$\Delta \mathrm{XE}_{\mathrm{t}-1}$ & 3.429 & $5.5983^{* * *}$ & ------ & ----- \\
\hline$\Delta \mathrm{ME}_{\mathrm{t}-1}$ & ------ & ------ & 0.847 & $5.747^{* * *}$ \\
\hline$\Delta \mathrm{ME}_{\mathrm{t}-2}$ & ----- & ------ & 0.266 & $3.034^{* *}$ \\
\hline$\Delta \mathrm{ME}_{\mathrm{t}-3}$ & ----- & ------ & -0.380 & $-1.974^{*}$ \\
\hline$\Delta \mathrm{DI}$ & -0.309 & -1.589 & 0.282 & $2.992^{* *}$ \\
\hline$\Delta \mathrm{DI}_{\mathrm{t}-1}$ & 0.255 & 1.413 & 0.544 & $2.819^{* *}$ \\
\hline$\Delta \mathrm{DI}_{\mathrm{t}-2}$ & -0.469 & $-2.313^{* *}$ & 0.789 & $4.602^{* * *}$ \\
\hline$\Delta \mathrm{Al}$ & 0.114 & $2.684^{* * *}$ & -0.058 & $-3.056^{* * *}$ \\
\hline$\Delta \mathrm{Al}_{\mathrm{t}-1}$ & 0.117 & $2.495^{* *}$ & -0.217 & $-8.378^{* * *}$ \\
\hline$\Delta \mathrm{Al}_{\mathrm{t}-2}$ & 0.085 & 1.764 & 0.245 & $4.354^{* * *}$ \\
\hline$\Delta \mathrm{JI}$ & -0.061 & $-2.843^{* *}$ & -0.076 & $-4.152^{* * *}$ \\
\hline$\Delta \mathrm{Jl}_{\mathrm{t}-1}$ & -0.085 & $-3.383^{* * *}$ & -0.075 & $-4.663^{* * *}$ \\
\hline$\Delta \mathrm{Jl}_{\mathrm{t}-2}$ & -0.046 & $-2.462^{* *}$ & -0.042 & $-4.565^{* * *}$ \\
\hline$\Delta \mathrm{Jl}_{\mathrm{t}-3}$ & ------ & ------ & 0.017 & 1.640 \\
\hline$\Delta \mathrm{EI}$ & -0.087 & -1.593 & 0.058 & 1.702 \\
\hline$\Delta \mathrm{El}_{\mathrm{t}-1}$ & -0.099 & $-2.003^{*}$ & 0.278 & $9.292^{* * *}$ \\
\hline$\Delta \mathrm{El}_{\mathrm{t}-2}$ & -0.149 & $-2.307^{* *}$ & -0.097 & $-2.838^{* *}$ \\
\hline$\Delta \mathrm{ER}$ & 0.850 & $2.964^{* *}$ & 0.712 & $2.639 * *$ \\
\hline$\Delta \mathrm{ER}_{\mathrm{t}-1}$ & ------ & ------ & -0.249 & -1.573 \\
\hline$\Delta \mathrm{ER}_{\mathrm{t}-2}$ & ------ & ------ & -0.506 & $-3.292^{* *}$ \\
\hline$\Delta \mathrm{ER}_{\mathrm{t}-3}$ & ------ & ------ & 0.460 & $3.493^{* *}$ \\
\hline \multicolumn{5}{|c|}{ Diagnostic Test Results } \\
\hline \multicolumn{2}{|c|}{ Adjusted R-squared } & 0.150 & \multicolumn{2}{|c|}{0.926} \\
\hline \multicolumn{2}{|c|}{ Normality (Jarque-Bera) } & $0.912(0.633)$ & \multicolumn{2}{|c|}{$1.287(0.525)$} \\
\hline \multicolumn{2}{|c|}{$\mathrm{ARCH}(1)$} & $0.186(0.669)$ & \multicolumn{2}{|c|}{$0.889(0.354)$} \\
\hline \multicolumn{2}{|c|}{ Serial Correlation LM(2) } & $0.878(0.442)$ & \multicolumn{2}{|c|}{$0.588(0.596)$} \\
\hline \multicolumn{2}{|c|}{ Ramsey RESET } & $0.094(0.763)$ & \multicolumn{2}{|c|}{$0.001(0.968)$} \\
\hline
\end{tabular}

Notes: Lag-lengths of the variables were determined by using the AIC method. ${ }^{*}, * *$, and ${ }^{* * *}$ indicate significance at $10 \%, 5 \%$ and $1 \%$ levels, respectively. Numbers in parentheses represent $p$-values.

Table 4: Error Correction Model Test Results

indicated that FDI inflows from the US, Japan, and the EU have significantly different impacts on Turkish export performance. More specifically, it was established that Japanese and EU FDI are export-oriented and thus contribute to the rapid growth of Turkish exports, while US FDI is anti-export-oriented and thus leads to decreases in Turkish exports to the EU market. It can also be suggested from the results that there is strong evidence for Kojima's hypothesis, since Japanese FDI affects Turkish 
export growth positively, while US FDI has a negative impact on Turkish exports to the EU market.

Similarly, the estimation results of the long-run import model showed that both domestic and foreign investments are the major sources of growth for Turkish imports, while the real exchange rate affects Turkish imports negatively. The estimation results also indicated that FDI inflows from the US, Japan, and the EU have different impacts on Turkish imports. In particular, FDI from the US and EU increases the level of Turkish imports by raising demands for foreign intermediate and capital goods, while FDI from Japan replaces Turkish imports on the EU market. This leads to the conclusion that FDI takes place in Turkey for different kinds of motivations; the first concentrated on both foreign and local markets, the second concentrated only on the local market. Overall, the impact of FDI inflows on the trade performance of any developing country cannot be established a priori since they depend on various characteristics of both the source and recipient countries. [

\section{References}

Abe, S. 1983. "ASEAN Dilemma: An Analysis of Interdependence between Japan and the ASEAN Countries", Sekai Keizai Hyoron, 27 (4): 10-16.

Arndt, H.W. 1974. "Professor Kojima on the Macroeconomics of Foreign Direct Investment", Hitotsubashi Journal of Economics, 15: 2635.

Bayoumi, T., P. Isard., S.A. Symansky. and T. Ito.1996. "Exchange Rate Movements and Their Impacts on Trade and Investment in the APEC Region", IMF Occasional Papers No. 145.

Brainard, S. 1993. "A Simple Theory of Multinational Corporations and Trade with a Trade-off between Proximity and Concentration", NBER Working Paper No. 4269.

Buckley, P. 1983. "Macroeconomic versus International Business Approach to Direct Foreign Investment: A Comment on Professor Kojima's Interpretation", Hitotsubashi Journal of Economics, 24: 95-100.

Cetin, R. 2005. An Empirical Analysis of the Impacts of Foreign Direct Investment on the Trade Performance of Turkey: 1970-1990, Ph.D. diss., Nottingham Trent University, Nottingham.

Dickey, D.A. and W.A. Fuller. 1979. "Distribution of the Estimators for Autoregressive Time Series with a Unit Root", Journal of the American Statistical Association, 74: 427-431.

Dunning, J.H. 1993. Multinational Enterprises and the Global Economy, Wokingham, England: Addison Wesley.

Eaton, J. and A. Tamura. 1994. "Bilateralism and Regionalism in Japanese and US Trade and Direct Foreign Investment Patterns", NBER Working Papers No. 4758.

Engle, R.F. and C.W.J. Granger. 1987. "Cointegration and Error Correction Representation, Estimation and Testing", Econometrica, 55: 251-276.

Frankel, J.A. and S.J. Wie. 1993. "Trade Blocs and Currency Blocs", NBER Working Papers No. 4335

Gagnon, J.E. 1993. "Exchange Rate Variability and the Level of International Trade", Journal of International Economics, 34: 269-287.
Geroski, P.A. 1979. "Review of Direct Foreign Investment by Kiyoshi Kojima", Economic Journal, 89: 62-64.

Goldberg, L.S. and M.W. Klein. 1997. "Foreign Direct Investment, Trade and Real Exchange Linkages in the Southeast Asia and Latin America", NBER Working Paper No. 6344.

Gullett, N.C. 1990. The Impact of Direct Foreign Investment on the Host Country Trade and Output: A Study of Japanese and US Investment in Colombia and Brazil, Ph.D. diss., Memphis State University.

Helpman, E. 1984. "A Simple theory of Trade with Multinational Corporations", Journal of Political Economy, 92: 451-471.

Herzer, D., F. N. Lehmann and B. Siliverstovs. 2004. “Export-Led Growth in Chile: Assessing the Role of Export Composition in Productivity Growth," Ibero-America Institute for Economic Research Discussion Papers.

Horstmann, I.J. and J.R.Markusen. 1992. "Endogenous Market Structures in International Trade", Journal of International Economics, 32: 109-129.

IMF. 2007. "International Financial Statistics", http://www.imfstatistics.org/imf/ (accessed November 26, 2007).

Johansen, S and K. Juselius. 1990. "Maximum Likelihood Estimation and Inference on Cointegration with Applications to the Demand for Money," Oxford Bulletin of Economics and Statistics, 52:169-211.

Kojima, K. 1973. "A Macroeconomic Approach to Foreign Direct Investment", Hitotsubashi Journal of Economics, 14: 1-21.

----.1975. "International Trade and Foreign Direct Investment: Substitutes or Complements", Hitotsubashi Journal of Economics, 16: 112.

---1982. "Macroeconomic versus International Business Approach to Direct Foreign Investment", Hitotsubashi Journal of Economics, 23: 119.

-----.1985. "Japanese and American Direct Foreign Investment in Asia: A Comparative Analysis", Hitotsubashi Journal of Economics, 26: 1-35.

-----1995. "Dynamics of Japanese Direct Investment in East Asia", Hitotsubashi Journal of Economics, 36: 93-124.

Lee, C.H. (1984). "On Japanese Macroeconomic Theories of Direct Foreign Investment", Economic Development and Cultural Change, vol. 32, pp. 713-723.

Mason, R.H. 1980. "A Comment on Professor Kojima's Japanese style versus American type of Technology Transfer", Hitotsubashi Journal of Economics, 20: 42-52

Leichenko, R.M. and R.A. Erickson. 1997. "Foreign Direct Investment and State Export Performance", Journal of Regional Science, 37 (2): $307-$ 329.

MacKinnon, J.G. 1996. "Numerical Distribution Functions for Unit Root and Cointegration Tests, Journal of Applied Econometrics", 11: 601-618.

Mankovska, N. 2001. The Relationship Between Foreign Direct Investment and Trade Flows in A Transition Economy: The Case of Ukraine, Master Thesis, Economics, National University of Kyiv-Mohyla Academy.

Markusen J.R. 1984. "Multinational, Multi-Plant Economies and the Gains from Trade", Journal of International Economics, 16: 205-226.

-----. 1995. "The Boundaries of Multinational Firms and the Theory of International Trade", Journal of International Economic Perspective, 9: 169-189.

Markusen, J.R. and A.J. Venables. 1998. "Multinational Firms and the New Trade Theory", Journal of International Economics, 46: 183-203.

Mundell, R.A. 1957. "International Trade and Factor Mobility", American Economic Review, 47: 321-335.

Naya, S. and E.D. Ramstetter. 1992. "Foreign Direct Investment in Asia's Developing Economies and Trade in the Asian and Pacific Region", in, Foreign Investment, Trade and Economic Cooperation in the Asian 
and Pacific Region, United Nations ESCAP Development Papers No. 1006.

Orr, J. 1991. "The Trade Balance Effects of Foreign Direct Investment in US Manufacturing", Federal Reserve Bank New of York Quarterly Review, 16: 63-76.

Perron, P. 1989. The great crash, the oil price shock and the unit root hypothesis, Econometrica, 57, 1361-1401.

Perron, P. 1997. Further evidence on breaking trend functions in macroeconomic variables, Journal of Econometrics, 80, 355-385.

Phillips, P.C.B. and P. Perron. 1988. "Testing for a Unit Root in a Time Series Regression", Biometrika, 75: 335-346.

Purvis, D.D. 1972. "Technology, Trade and Factor Mobility", Economic Journal, 82 (237): 991-999.

Ramstetter, E.D. 1986. The Impacts of Direct Foreign Investment on Host Country Trade and Output: A Study of Japanese and United States Investment in Korea, Taiwan, and Thailand, Ph.D. diss., Department of Economics, University of Colorado.

Sun, H. 2001. "Foreign Direct Investment and Regional Export Performance in China", Journal of Regional Science, 41 (2): 317-336.

Trade-EC-Europa. 2007. "Turkey: EU Bilateral Trade and Trade with the World",

http://trade.ec.europa.eu/doclib/docs/2006/september/tradoc 113456. pdf (accessed March 18, 2008).

UNCTAD. 2007. World Investment Report,

http://www.unctad.org/en/docs/wir2007_en.pdf (accessed March 18, 2008).

Ulgen, S. and Y. Zahariadis. 2004. "The Future of Turkish-EU Trade Relations Deepening vs Widening", EU-Turkey Working Paper No. 5.

Vernon, R. 1966. "International Investment and International Trade in the Product Cycle", Quarterly Journal of Economics, 80: 190-207.

\section{Appendix I: Definitions of Variables and Data} Sources

Dependent Variables:

$X E=$ Turkish exports to the EU at FOB prices, expressed in real terms using the export price index $(1987=100)$. Source: International Trade Statistics Yearbook of United Nations and State Planning Organisation (SPO). The relevant export price index was collected from OECD National Accounts

$M E=$ Turkish imports from the EU at CIF prices, expressed in real terms using the import price index (1987=100). Source: International Trade Statistics Yearbook of United Nations and the SPO. The relevant import price index was collected from OECD National Accounts

Explanatory Variables:

$\mathrm{DI}=$ Gross fixed capital formation, expressed in real terms using the wholesale price index $(1987=100)$. Source: the SPO and the wholesale price index were obtained from the IMF International Financial Statistics.
$E R=\quad$ Real exchange rate, measured by the real effective exchange rate index for Turkish lira. Source: the SPO.

$\mathrm{Al}, \mathrm{Jl}, \mathrm{El}=$ the US, Japanese, and the EU FDI annual inflows to Turkey respectively, at constant prices $(1987=100)$. Actual FDI data are available from 2001. The data between 1976 and 2001 collected at a permit level. The permit values of the relevant FDI are transformed to actual FDI data by the realisation ratio for aggregate FDI. Source: Foreign Investment Department (1976-2001) and Republic of Turkey Prime Ministry Undersecretariat of Treasury (2002-2006)

In this study, since foreign currencies are expressed in terms of Turkish lira an increase in the real effective exchange rate index represents a real depreciation of the Turkish lira. Real effective exchange rate was calculated as the weighted average of a basket of foreign currencies according to trade shares of the major trading partner countries. All variables enter the regressions in logarithmic form, so that the estimated regression coefficients are interpreted as elasticities. In estimating our trade models, Eviews 5.1 econometric programme was used. 


\section{Appendix II: Generalized Impulse Responses of Long-Run Relation to One Standard Deviation Shock}
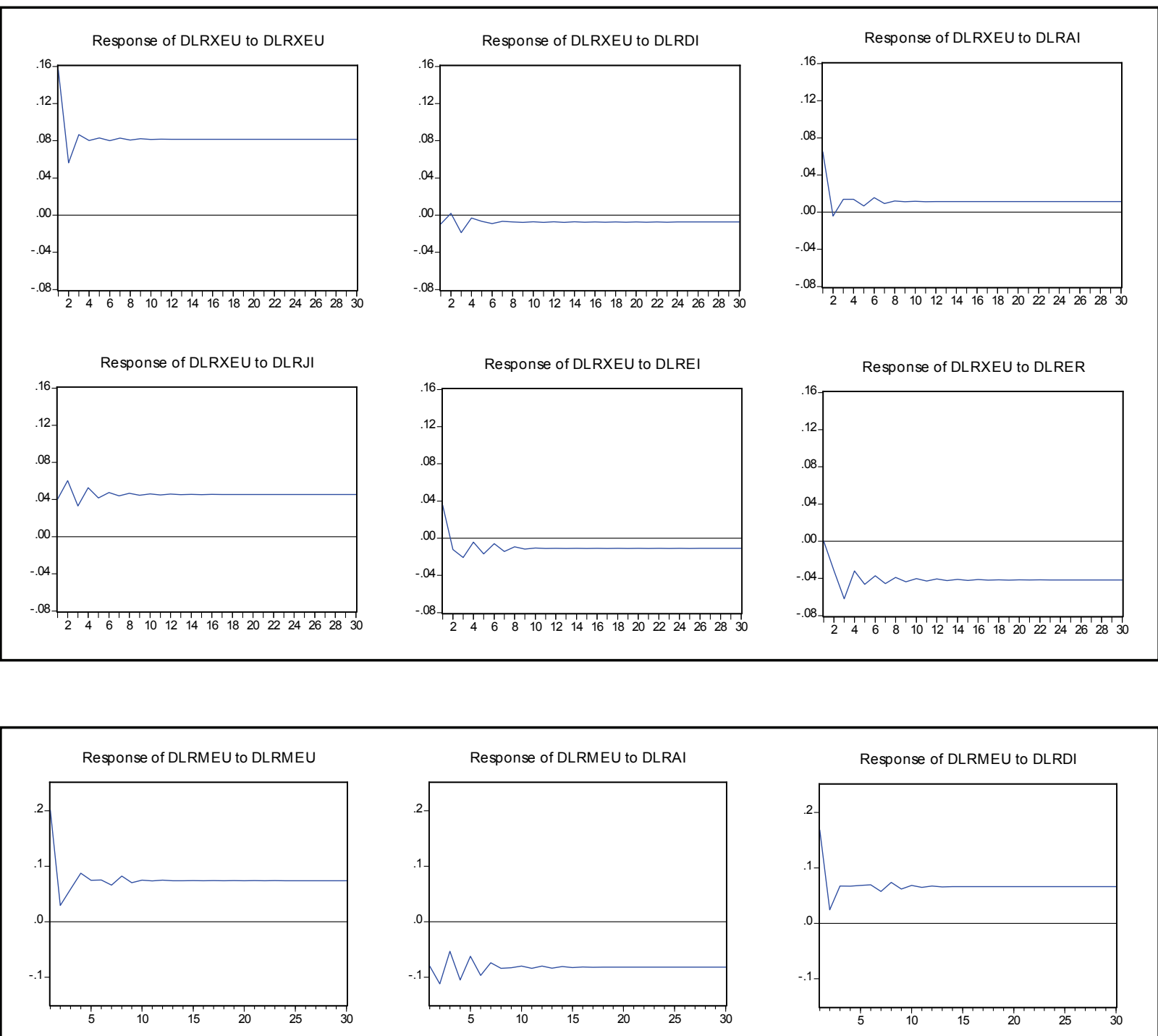

Response of DLRMEU to DLREI

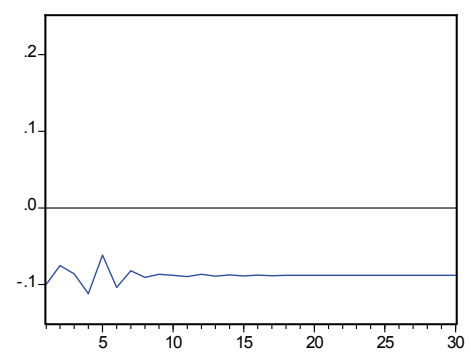

Response of DLRMEU to DLRER

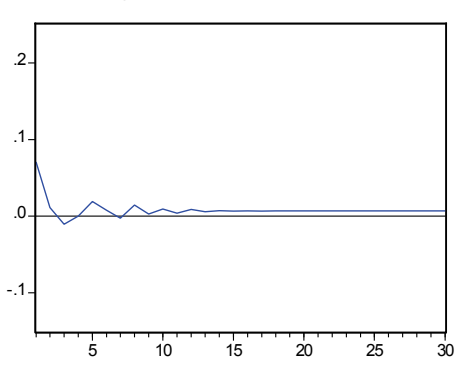

Response of DLRMEU to DLRJI

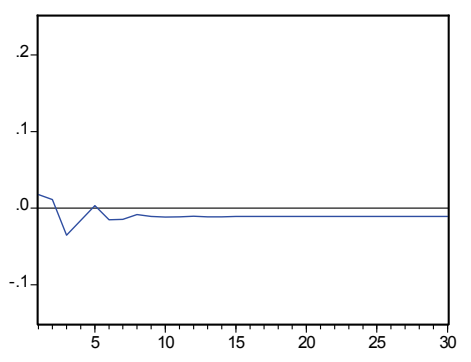

